\title{
Evaluation of lipid metabolizing enzymes: Paraxonase1 (PON1) and lecithin cholesterol acyltransferase (LCAT) activities in children with nephrotic syndrome
}

\author{
Raghad J. Ali ${ }^{1}$, Rayah S. Baban ${ }^{2} \odot$ and Shatha H. Ali ${ }^{3}$ \\ ${ }^{1}$ Baghdad Medical City, Ministry of Health, Baghdad, Iraq \\ ${ }^{2}$ Department of Chemistry and Biochemistry, College of Medicine, Al-Nahrain University, Baghdad, Iraq \\ ${ }^{3}$ Department of Pediatrics, College of Medicine, Al-Nahrain University, Baghdad, Iraq
}

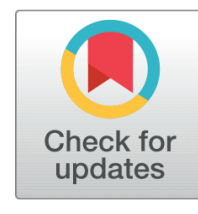

Received 15-12-2020

Revised 18-12-2020

Accepted 25-3-2021

Published 30-3-2021

\section{Corresponding Author}

Raghad J. Ali

raghad78r@gmail.com

Baghdad Medical City, Ministry of Health, Baghdad, Iraq

DOI https://doi.org/10.47419/ bjbabs.v2i01.38

\section{Pages: 48-59}

Distributed under the terms of the Creative Commons

Attribution-NonCommercial 4.0 International (CC-BY-NC 4.0), which permits use for any non-commercial purpose, distribution, and reproduction in any medium, provided that the original work is properly cited.

Copyright: (c) 2021 Raghad J. Ali, Rayah S. Baban, Shatha $\mathrm{H}$. Ali

\section{OPEN ACCESS}

\section{ABSTRACT}

Background: The most common glomerular disorder in children is nephrotic syndrome, associated with high morbidity despite notable advances in its treatment. Many of the nephrotic syndrome complications, including the increased risk of atherosclerosis and thromboembolism, can be linked to dysregulated lipid metabolism and dyslipidemia. Paraoxonase enzyme is responsible for the most of the antioxidant properties of HDL, thus preventing the formation of atherogenic ox-LDL molecules, and Lecithin Cholesterol acyltransferase is intimately involved in HDL maturation and is a key component of the reverse cholesterol transport pathway, which removes excess cholesterol molecules from the peripheral tissues to the liver for excretion.

Objectives: The present study aimed to investigate the serum activities of paraoxonase-1(PON-1) and lecithin cholesterol acyltransferase (LCAT) in children with nephrotic syndrome in an active phase (as newly diagnosed or old cases with acute relapse). Also, to study any correlation exists between paraoxonase-1 activity and lipid profile.

Methods: This study consists of Group 1 with 40 cases of nephrotic syndrome in the age group of (2-14 years) and Group 2 with 40 age and sex-matched healthy controls. Lipid profile and paraoxonase activity, Lecithin Cholesterol acyltransferase activities were measured in both groups' serum samples.

Results: Statistical analysis of student's t-test showed that the mean levels of Total Cholesterol, Triglycerides, LDL were significantly increased in Group 1 when compared to Group $2(\mathrm{p}<0.001)$. PON1 and Lecithin Cholesterol acyltransferase levels were significantly lower in Group 1 compared to Group 2, and there is no significant difference among nephrotic groups.

Conclusions: Both Paraoxonase-1 enzyme and Lecithin Cholesterol acyltransferase are considered good promising predictors for nephrotic syndrome and other parameters such as LDL, HDL, and T.G. The significantly decreased Paraoxonase-1 enzyme and Lecithin Cholesterol acyltransferase activities result in increased oxidation of LDL, thus accelerating atherosclerosis. 
Keywords fluorescent assay, lecithin cholesterol acyltransferase, nephrotic syndrome, PON1, LCAT

\section{INTRODUCTION}

The most common glomerular disorder in children is nephrotic syndrome (NS). Nephrotic syndrome is manifested as heavy (nephrotic-range) proteinuria ( $>40 \mathrm{mg} / \mathrm{h} / \mathrm{m} 2$ or $>50 \mathrm{mg} / \mathrm{kg} /$ day or protein/creatinine ratio $>0.2 \mathrm{~g} / \mathrm{mmol}(>2 \mathrm{~g} / \mathrm{g})$.

Many of the nephrotic syndrome complications, including the increased risk of atherosclerosis and thromboembolism, can be linked to dysregulated lipid metabolism and dyslipidemia. ${ }^{1}$ The paraoxonase 1 (PON1) is a serum enzyme involved in lipid metabolism. ${ }^{2,3}$ It is bound to high-density lipoprotein (HDL) and acts as an antioxidant for the low-density lipoproteins (LDL) by hydrolyzing lipid peroxides, thus preventing LDL oxidation and subsequently leading to an anti-atherogenic effect. ${ }^{4-6}$

Paraoxonase 1 (PON1) is a free radical scavenging system that plays a role in detoxifying a wide range of substrates such as organophosphate compounds and carcinogenic lipidsoluble radicals from lipid peroxidation. It catalyzes the hydrolysis of multiple compounds such as arylesterase, lactones and hydroperoxides. ${ }^{7}$ Human LCAT is a glycoprotein made up of 416 amino acids circulating in plasma associated with lipids and apolipoproteins in the HDL. ${ }^{8}$ LCAT, principally synthesized and secreted by the liver, is the only known plasma enzyme catalyzing the esterification of free cholesterol in HDL particles. ${ }^{9}$ LCAT-mediated cholesterol esterification by converting cholesterol and phosphatidylcholine into cholesteryl ester and lysophosphatidylcholine is critical for HDL maturation and reverse cholesterol transport (RCT) which removes excess cholesterol molecules from the peripheral tissues to the liver for excretion. ${ }^{10}$

LCAT esterifies free cholesterol on the surface of HDL, forming cholesteryl esters which then partition into the lipoprotein core, resulting in mature spherical HDL particles. ${ }^{11}$ Many reviews have dealt with the issue of LCAT and its atherogenic aspects. ${ }^{12-15}$

The present study was taken up to study the serum lipids and PON1, LCAT activity in children with nephrotic syndrome and study the correlation of lipid parameters with PON1 activity and LCAT activity.

\section{MATERIALS AND METHODS Study design and subjects}

A case-control study was conducted at Al-Imamain Al-Khadimain Medical City and the Department of Chemistry and Biochemistry, College of Medicine, Al-Nahrain University from $1^{\text {st }}$ January until $31^{\text {st }}$ November 2019. 
The study participant included two groups: Group 1 (patients) consisted of 40 children with confirmed cases of nephrotic syndrome in an active phase (as newly diagnosed or old cases with acute relapse), with age between 2 to 14 years of both genders. At the same time, Group 2 (control) consisted of 40 (ages and sex-matched) healthy controls. The patients were diagnosed and treated with followed up in the Pediatric Nephrology unit at Al Imamain Khadimain Medical City and Baghdad Welfare Teaching Hospital in the Medical City of Baghdad. The authors performed a well-constructed questionnaire and direct interview with the parents of patients and control group, and all the doctors were involved before collecting the blood sample. According to steroid responsiveness, data collected included age, sex, age of onset of N.S., Type of N.S., and relapses frequency. Some of the information's were taken from the files record as well. Body weight and Height measurements were perfumed to all study groups.

Diagnosis of N.S. was made according to the following criteria:

Relapse: heavy proteinuria $>40 \mathrm{mg} / \mathrm{h} / \mathrm{m} 2$ or $>50 \mathrm{mg} / \mathrm{kg} /$ day, Albustix $\geq+++$ for 3 consecutive days after having been in remission. Frequent relapses: 2 or more relapses within six months of initial response or 4 or more relapses within one year, hypo-albuminemia $<2.5$ g/dL, oedema and hyperlipidemia. ${ }^{2,3}$ The exclusion criteria are Familial hyperlipidemia, Patients with other renal pathology, Patients with liver disease, diabetic patients, urolithiasis and malnourished children.

The Institutional Review Board (IRB) of the College of Medicine, Al-Nahrain University approved this study. All samples were obtained with informed consent following the Al-Imamain Al-Kadhimain Medical City, Central Child Teaching Hospital and Children Welfare Teaching Hospital declaration.

\section{Blood sampling}

A venous blood sample was collected by taking at morning in $(8: 30 \mathrm{am})$, the total of blood $(5 \mathrm{ml})$ from each fasting patient and healthy human, in non-heparinized tubes( plain tube) to isolate serum by centrifugation at $3000 \mathrm{rpm}$ for $10 \mathrm{~min}$ and the serum was divided into two portions and placed in a cool-Box under a septic condition first one kept in two Eppendorf tubes in $\left(-80^{\circ} \mathrm{C}\right)$ until estimation for (PON1 and LCAT) enzyme activity and the other second portion for measuring lipids profile, included serum cholesterol, Lowdensity lipoprotein (LDL), High-density lipoprotein (HDL), Very low-density lipoprotein (VLDL) and triglycerides (T.G.), blood glucose Blood urea, S.creatinne, Total serum protein and serum albumin at the same day. These were assessed using an Auto analyzer (Siemens japan). The control subjects were evaluated by a consultant Pediatric Nephrologist to ensure the absence of any renal disease.

\section{Analysis of paraoxonase activity}

PON1 activity was tested by fluorescence assay Kit (ab241044) Abcam company ${ }^{16}$ that enables rapid measurement of Paraoxonase 1 (PON1) activity, utilizing a fluorogenic sub- 
strate that is converted into a highly fluorescent product $(\mathrm{Ex} / \mathrm{Em}=368 / 460 \mathrm{~nm})$ in kinetic mode for 60 minutes at $37^{\circ} \mathrm{C}$. Standards may be read in end-point mode using Glow max reader (Promega company). The assay is simple to perform, high-throughput adaptable and can detect a minimum of $2.0 \mu \mathrm{U}$ paraoxonase activity with a sample volume of $5 \mu \mathrm{L}$. This ensures dramatically greater sensitivity than U.V. or colorimetric assays and eliminates the need for dangerous toxic substrates.

\section{Analysis of LCAT activity}

It is simple, fluorometric assay that quantitatively measures LCAT phospholipase activity (LCAT Activity Assay Kit (ab242306) - Abcam) ${ }^{17}$ in plasma, serum, and lysates in a 96-well microtiter plate format. Each kit provides sufficient reagents to perform up to 100 assays, including blanks and unknown samples. We should Prepare all reagents and samples as instructed. We added $50 \mu \mathrm{L}$ of standards or unknown samples into a 96-well plate and the desired amount of LCAT inhibitor to the appropriate samples and incubate them for 1 hour at $37^{\circ} \mathrm{C}$; after that, the reaction was initiated by adding $50 \mu \mathrm{L}$ of the LCAT Reaction Reagent to each well and mix. These are Incubated for 3 to 18 hours at $37^{\circ} \mathrm{C}$. Finally, the reaction stopped by adding $100 \mu \mathrm{L}$ of the $2 \mathrm{X}$ stop solution to each well and immediately read at EX:342/EM:400nm.

\section{Statistical analysis}

The data were analyzed with SPSS version $26.0^{18}$ software. Results were expressed as Mean \pm SE. The probability also examined using the student's t-test, and the Chi-square test was used for group comparisons. Karl Pearson's correlation coefficient measured the relationship between variables. A statistical significance was set at $5 \%$ level of significance $(p<0.05)$.

\section{RESULTS}

The total number of patients and control in the present study was 80; there were 48 (60\%) males and females $32(40 \%)$, with male to female ratio of 1.5: 1. Demographic parameters of both patients and control are shown in (Table 1). There was no statistical difference in the sex distribution (p-value 0.994 ) and mean age between the two groups both the groups were comparable.

All subjects (patients and control) were subjected to measuring serum urea, creatinine, albumin, lipid profile, PON1, LCAT activity shown in (Table 2). Statistical analysis of student's t-test showed that the mean levels of S. Albumin significantly lowered in N.S. patients compared to control $(1.33 \pm 0.12$ vs. $4.12 \pm 0.06)$ respectively at $\mathrm{p}<0.001$ whereas $S$.Ch, TG, LDL, were significantly increased in Group1 (Patients) when compared to Group 2(control) at $(\mathrm{p}<0.001)$. The levels of PON1enzyme activity and LCAT activity levels are significantly 
Table 1 The mean age levels of patients and control.

\begin{tabular}{llll} 
Groups & Age (years) & & $\boldsymbol{p}$-value \\
& Patients' group & Control group & \\
Males & $7.25 \pm 0.73$ & $7.24 \pm 0.73$ & 0.994 \\
Females & $6.95 \pm 0.93$ & $7.13 \pm 0.85$ & 0.891 \\
Total & $7.14 \pm 0.57$ & $7.20 \pm 0.55$ & 0.994 \\
$\boldsymbol{p}$-value & 0.798 & 0.921 & \\
\hline
\end{tabular}

$p>0.05$ (not significant)

lower in Group 1 compared to Group $2(p<0.001)$.

In tables 3 and 4 , comparison between the PON1enzyme activity and LCAT enzyme activity among the patient group presented: 10 were newly diagnosed cases of N.S., while 30 were old cases with frequent relapses. Statistical analysis demonstrated that PON1enzyme activity insignificant difference between ND $(123.0 \pm 9.87 \mu \mathrm{U} / \mathrm{ml})$, F.R. $(129.80 \pm 5.79$ $\mu \mathrm{U} / \mathrm{ml}$ ), and LCAT enzyme activity insignificant difference between N.S. patients' group $\mathrm{ND}(93.60 \pm 4.94 \mu \mathrm{U} / \mathrm{ml})$, F.R. $(94.70 \pm 3.15 \mu \mathrm{U} / \mathrm{ml})$.

\begin{tabular}{llll}
\hline \multicolumn{2}{l}{ Table 2 Study parameters levels of control and nephrotic syndrome patients } & \\
Groups & mean \pm S.E. (Years) & & Probability \\
& Patients group $(\mathrm{n}=40)$ & control group $(\mathrm{n}=40)$ & \\
BMI $\left(\mathrm{Kg} / \mathrm{m}^{2}\right)$ & $23.61 \pm 1.39$ & $18.60 \pm 0.48$ & $\mathbf{0 . 0 1 0}$ \\
Blood Urea $(\mathrm{mg} / \mathrm{dl})$ & $43.52 \pm 6.69$ & $27.49 \pm 0.56$ & 0.083 \\
Serum creatinine $(\mathrm{mg} / \mathrm{dl})$ & $1.56 \pm 0.89$ & $0.79 \pm 0.02$ & 0.571 \\
Blood sugar $(\mathrm{mg} / \mathrm{dl})$ & $101.13 \pm 1.51$ & $95.07 \pm 1.35$ & $\mathbf{0 . 0 2 8}$ \\
Serum albumin $(\mathrm{mg} / \mathrm{dl})$ & $1.33 \pm 0.12$ & $4.12 \pm 0.06^{* *}$ & $\mathbf{0 . 0 0 0 1}$ \\
Serum cholesterol $(\mathrm{mg} / \mathrm{dl})$ & $382.93 \pm 9.82$ & $163.12 \pm 2.66^{* *}$ & $\mathbf{0 . 0 0 0 1}$ \\
Serum triglyceride $(\mathrm{mg} / \mathrm{dl})$ & $333.80 \pm 24.49$ & $132.93 \pm 2.09^{* *}$ & $\mathbf{0 . 0 0 0 1}$ \\
Serum HDL-cholesterol $(\mathrm{mg} / \mathrm{dl})$ & $39.80 \pm 1.28$ & $62.61 \pm 2.25^{\star *}$ & $\mathbf{0 . 0 0 0 1}$ \\
Serum LDL-cholesterol $(\mathrm{mg} / \mathrm{dl})$ & $201.25 \pm 13.62$ & $75.39 \pm 2.69^{\star *}$ & $\mathbf{0 . 0 0 0 1}$ \\
S. Paraxonase Activity $(\mu \mathrm{U} / \mathrm{ml})$ & $128.10 \pm 4.95$ & $327.54 \pm 6.45^{* *}$ & $\mathbf{0 . 0 0 0 1}$ \\
LCAT activity $(\mathrm{RFU})$ after $18 \mathrm{hr}$ & $94.43 \pm 2.64$ & $148.27 \pm 5.98^{\star *}$ & $\mathbf{0 . 0 0 0 1}$ \\
\hline
\end{tabular}

$p>0.05$ (not significant), ${ }^{*} p<0.05$ (significant), ${ }^{* *} p<0.001$ (highly significant)

Table 3 S. paraoxonase activity mean in patients' group

\begin{tabular}{llll} 
Groups & NO. & S. Paraxonase Activity mean \pm S.E. $(\mu \mathbf{U} / \mathbf{m l})$ & $P$ \\
ND & 10 & $123.0 \pm 9.87$ & 0.559 \\
FR & 30 & $129.80 \pm 5.79$ & \\
\hline
\end{tabular}

ND: Newly diagnosed N.S. patients

FR: Frequent relapse N.S. patients 
Table 4 LCAT activity means patients' group

\begin{tabular}{ll|ll} 
Groups & NO. & LCAT activity mean \pm SE (RFU) after $\mathbf{1 8}$ hours & $P$ \\
ND & 10 & $93.60 \pm 4.94$ & 0.859 \\
F.R. & 30 & $94.70 \pm 3.15$ & \\
\hline
\end{tabular}

ND: Newly diagnosed N.S. patients

FR: Frequent relapse N.S. patients

\section{Correlation between the studied parameters in patient group}

The relationship between all parameters included in the current work concerning biochemical measurements was studied using Pearson correlation analysis; the results are presented in (Table 5). This study showed a highly significant $(\mathrm{P}<0.01)$ correlation between S. paraoxonase activity levels and Serum albumin, HDL (P-value 0.0001, $r=0.852, r=0.652$ respectively).

There was a significant $(\mathrm{P}<0.05)$ correlation between $\mathrm{S}$. paraoxonase activity and urea level in N.S. patient P-value 0.021, $\mathrm{r}=(-0.256)$. No significant correlation was reported from $\mathrm{S}$. paraoxonase activity with Creatinine $\mathrm{P}$-value $=0.221, \mathrm{r}=(-0.146)$ negative Correlation.

\begin{tabular}{|c|c|c|}
\hline $\begin{array}{l}\text { Laboratory parameters for } \\
\text { patients Nephrotic Syndrome }\end{array}$ & S. paraxonase activity (r-value) & P-value \\
\hline Urea & $-0.256^{\star}$ & 0.021 \\
\hline Creatinine & $-0.146 \mathrm{NS}$ & 0.221 \\
\hline Serum albumin & $0.852^{\star *}$ & 0.0001 \\
\hline Cholesterol & $-0.751^{* *}$ & 0.0001 \\
\hline TG & $-0.616^{\star *}$ & 0.0001 \\
\hline HDL & $0.652^{* *}$ & 0.0001 \\
\hline LDL & $-0.722^{\star *}$ & 0.0001 \\
\hline LCAT & $0.631^{* *}$ & 0.0001 \\
\hline
\end{tabular}

* Correlation is significant at the 0.05 level (2-tailed).

${ }^{*}$ Correlation is significant at the 0.01 level (2-tailed).

${ }^{*}(P<0.05),{ }^{* *}(P<0.01)$, NS: Non-significant

\section{DISCUSSION}

In agreement with previous studies, ${ }^{19-22}$ children in group 1 had significantly increased levels of T.C., T.G., LDL and VLDL in comparison to Group 2 ( $\mathrm{p}<0.001)$. (Table2) show that a significant decrease in serum albumin means levels in children with the nephrotic syndrome than healthy control; this result agreed with the studies ${ }^{23,24}$ in which nephrotic syndrome in children characterized by hypoalbuminemia (serum albumin $\leq 25 \mathrm{~g} / \mathrm{l}$ ). Hypoal- 


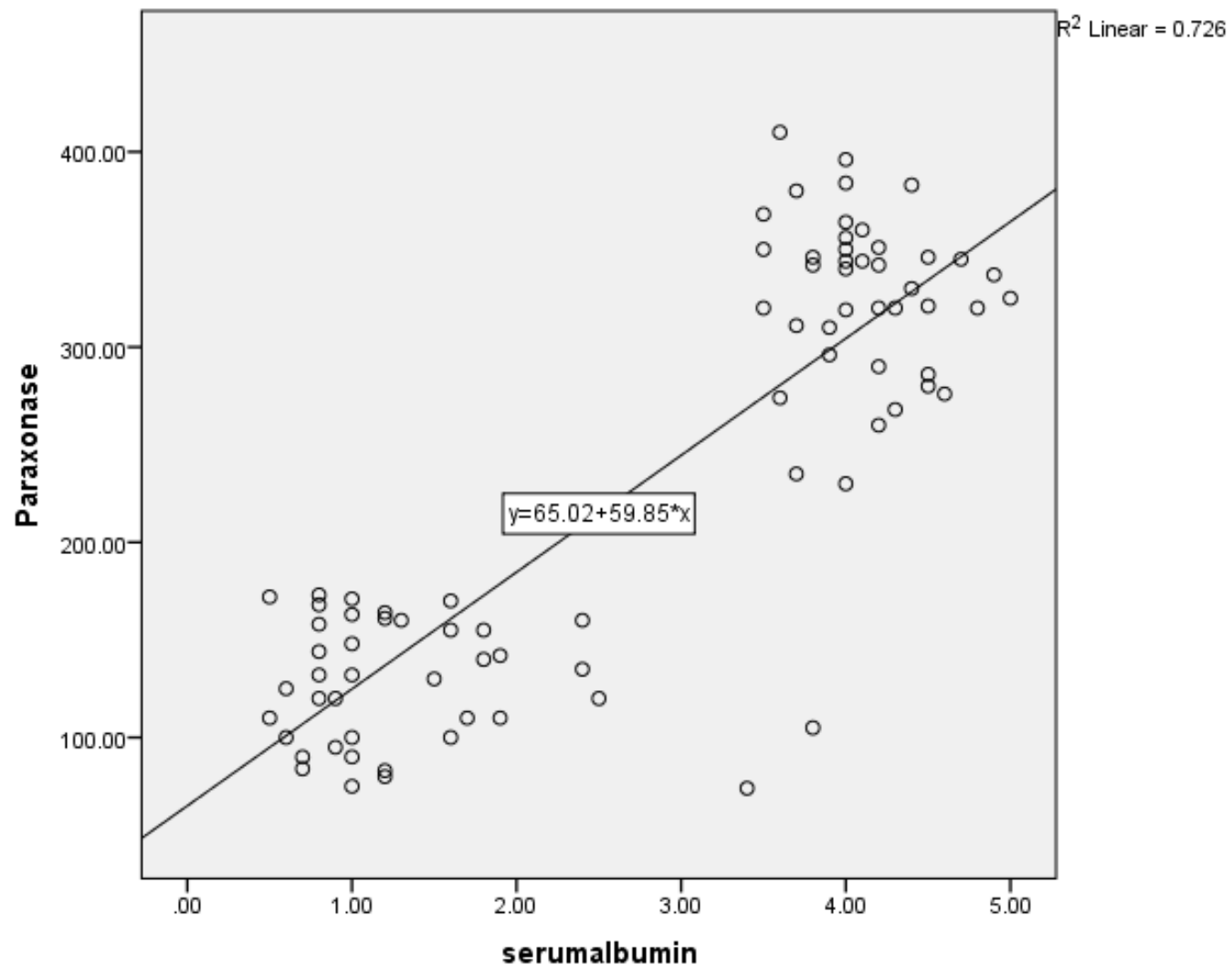

Figure 1 The correlation between S. paraxonase activity and serum albumin levels in patients group

buminemia outcomes from urinary losses of protein during proteinuria, scanty reparations by liver synthesis, and probably, increased catabolism of albumin. The main problem in hypoalbuminemia pathogenesis is the disability of the nephrotic liver to raise the synthesis of protein (albumin) to compensate for urinary losses. However, a normal liver synthesizes (12-14) gram albumin per day and can rising production three-fold in times of request. ${ }^{25}$ Further, in this table, the activity of enzyme PON1 that hydrolyzes oxidized lipids is decreased significantly in Group 1 compared to Group 2. Reduced PON1 activity could be a result of increased oxidative stress and/or reduced HDL levels. This is in accordance with studies done by researchers. ${ }^{20,22,26}$

PON-1 is an enzyme that protects against atherosclerosis by preventing lipid oxidation, and its level is decreased in chronic kidney disease. Its main function is binding to HDL and protecting LDL lipid peroxidation. Moreover, an inverse association was demonstrated between oxidative stress and PON-1 as a potent HDL-associated antioxidant enzyme ${ }^{26}$.

The (Table2) reveals the effect of LCAT activity on patients children with nephrotic syndrome compared to healthy children. There was a highly significant difference in the mean LCAT enzyme activity of patients compared to control $(\mathrm{p}<0.0001)$. When free cholesterol enters the intravascular space, it encounters the LCAT. As a relatively small soluble glycoprotein $(67 \mathrm{kDa})$, LCAT operates in an aqueous plasma medium with less or more 


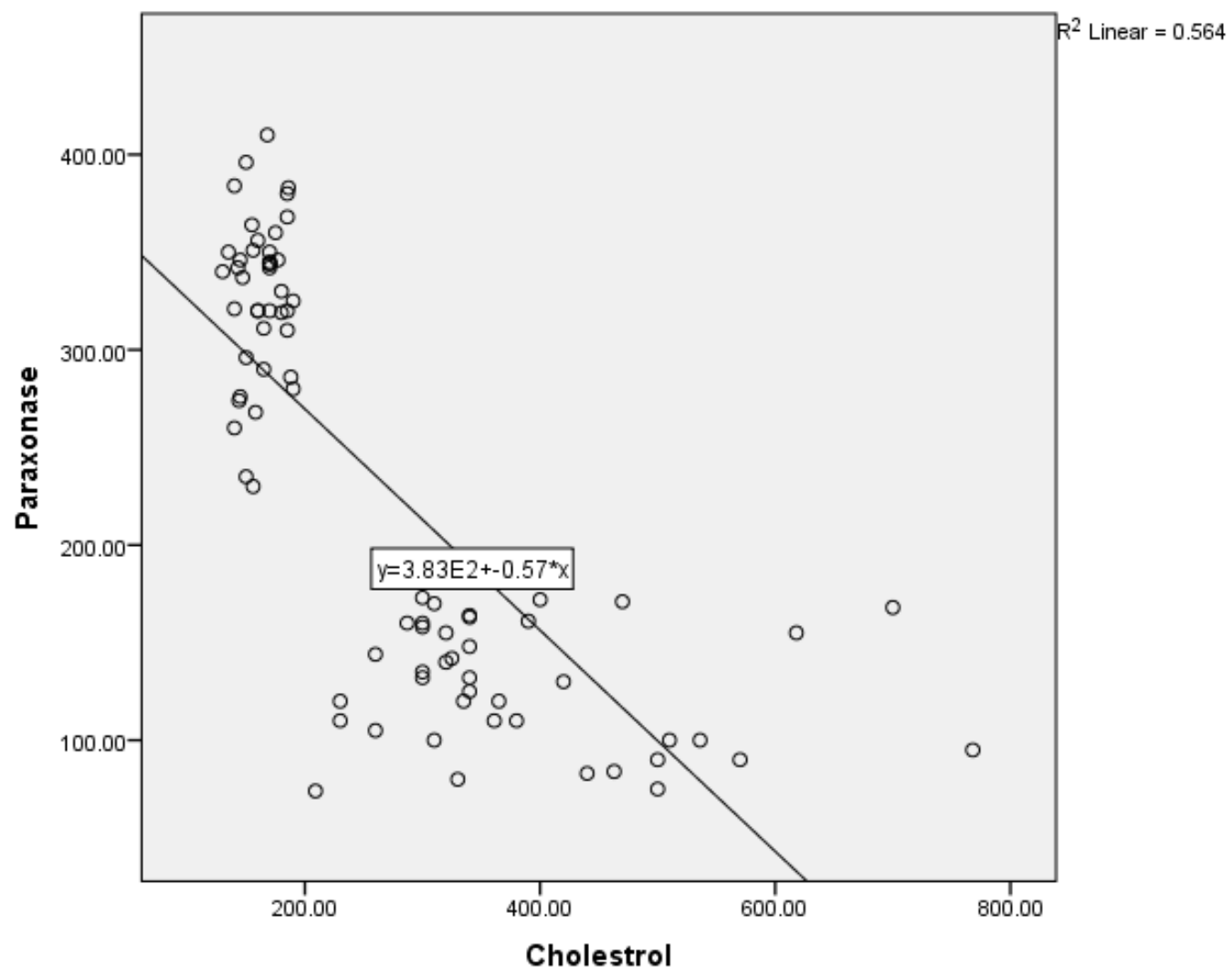

Figure 2 The correlation between S. paraxonase activity and serum cholesterol levels

hydrophobic components. Therefore, LCAT and cholesterol esterification rate's effectiveness will depend on many factors such as the physicochemical nature of the cholesterolphospholipid bilayer. ${ }^{27,28}$ The size of HDL, LDL and VLDL particles and activity of LCAT probably represent the most vital connection with the atherogenic plasma profile. The associations of high-density lipoprotein subclasses and apolipoproteins with ischemic heart disease and coronary atherosclerosis were found already in the eighties. ${ }^{28}$ On the other hand, two biomarkers - FERHDL (fractional esterification rate in HDL) and atherogenic index of plasma (AIP) [log (TG/HDL-C)] can offer a benefit to identifying the risk of cardiovascular disease (CVD). They both reflect the rate of cholesterol esterification by LCAT and the composition of lipoprotein subpopulations that controls this rate. ${ }^{25}$

Both Table 3 and Table 4 shows an insignificant difference between PON1 and LCAT among types of N.S. cases in an active phase (newly diagnosed or old cases with acute relapse). Aydin, in his study, demonstrated greater oxidative stress and decreased antioxidants in the active phase of steroid-sensitive N.S. and while patients receive steroids than during full remission. 29

Both newly diagnosed (N.D.) and relapsing patients are regarded as an active state of the disease and they were started on Steroid therapy, this can explain low PON 1 and LCAT activity as antioxidants in this study with an insignificant difference. 
In (Table5) it was found a significant correlation between lipid profile parameters- T.C., T.G., HDL, LDL, VLDL and PON1 within the patient's group and a significant negative correlation between (LDL and PON1) and a significant positive correlation between (HDL and PON1) in group 1 this result agreed with the studies. ${ }^{4,30}$ Both PON1 and LCAT considered as good promising predictors for nephrotic syndrome in addition to other parameters LDL, HDL, T.G. However, the availability of the fluorometric method is not common. Those patients with atherosclerotic dyslipidemia and significantly decreased PON1 and or LCAT activity result in increased LDL oxidation, accelerating atherosclerosis.

\section{CONCLUSIONS}

Decreased levels of PON1 and LCAT activities in children with nephrotic syndrome. Also, a high correlation was found between PON1 and LCAT activities and reduced serum albumin as well as with elevated serum cholesterol.

Further prospective studies with a larger sample size are required to clarify this effect of PON1 on the permeability of the glomeruli of children with nephrotic syndrome.

\section{ACKNOWLEDGMENTS}

The authors would like to thank all efforts participated in the practical part of this work, especially the staff of the hospitals.

\section{DECLARATIONS}

\section{Authors' contributions}

All authors have equally contributed to the practical part of this work. RSB supervised the work and all authors reviewed and approved the paper before publication.

\section{Conflicts of interest}

The authors declare no conflict of interest.

\section{Ethical approvals}

The Institutional Review Board (IRB) of the College of Medicine, Al-Nahrain University approved this study. All samples were obtained with informed consent following the AlImamain Al-Kadhimain Medical City, Central Child Teaching Hospital and Children Welfare Teaching Hospital declaration.

\section{Data availability}

The data associated with this work can be requested from the corresponding author. 


\section{Funding resources}

This work was't receive any fund.

\section{REFERENCES}

1. Agrawal S, Zaritsky JJ, Fornoni A, Smoyer WE. Dyslipidaemia in nephrotic syndrome: mechanisms and treatment. Nature Reviews Nephrology. 2018;14(1):57-70. Available from: 10.1038/nrneph.2017.155;https://dx.doi.org/10.1038/nrneph.2017. 155.

2. Niaudet P, Boyer O. Idiopathic Nephrotic Syndrome in Children: Clinical Aspects. In: E A, and Niaudet P HW, N Y, F E, S G, editors. Pediatric Nephrology. Springer, Berlin, Heidelberg; 2016. p. 839-882. Available from: https://doi.org/10.1007/9783-662-43596-0_24.

3. Gbadegesin R, Smoyer WE. Nephrotic Syndrome. In: Geary DF, Schaefer F, editors. Comprehensive Pediatric Nephrology; 2008. p. 205-218. Chapter 12.

4. Mansour SA, Neemat-Allah MAA, Shal ASE, Ibrahim SSAEA. The Value of Estimating Paraoxonase Activity in Nephrotic Children. The Egyptian Journal of Hospital Medicine . 2020;80(2):852-856. Available from: 10.12816/EJHM.2020.100200.

5. Kowalska K, Socha E, Milnerowicz H. The role of paraxonase in cardiovascular disease. Annals of Clinical and Laboratory Science. 2015;45(2):226-233.

6. Milaciu MV, Ștefan Cristian Vesa, Bocşan IC, Ciumărnean L, Sâmpelean D, Negrean V, et al. Paraoxonase-1 Serum Concentration and PON1 Gene Polymorphisms: Relationship with Non-Alcoholic Fatty Liver Disease. Journal of Clinical Medicine. 2019;8(12):2200-2200. Available from: 10.3390/jcm8122200; https://dx.doi.org/10. $3390 / j \mathrm{~cm} 8122200$.

7. Dias CG, Batuca JR, Marinho AT, Caixas U, Monteiro EC, Antunes AMM, et al. Quantification of the arylesterase activity of paraoxonase-1 in human blood. Anal Methods. 2014;6(1):289-294. Available from: 10.1039/c3ay41527a;https://dx.doi. org/10.1039/c3ay41527a.

8. Franceschini G, Maderna P, Sirtori CR. Reverse cholesterol transport: Physiology and pharmacology. Atherosclerosis. 1991;88(2-3):99-107. Available from: 10.1016/ 0021-9150(91)90073-c;https://dx.doi.org/10.1016/0021-9150(91)90073-c.

9. Rosenson RS, Brewer HB, Davidson WS, Fayad ZA, Fuster V, Goldstein J, et al. Cholesterol efflux and atheroprotection: advancing the concept of reverse cholesterol transport. Circulation. 2012;125(15):1905-1919. Available from: 10.1161/ CIRCULATIONAHA.111.066589.

10. Czarnecka H, Yokoyama S. Regulation of Cellular Cholesterol Efflux by Lecithin:Cholesterol Acyltransferase Reaction through Nonspecific Lipid Exchange. Journal of Biological Chemistry. 1996;271(4):2023-2028. Available from: 10.1074/ jbc.271.4.2023; https://dx.doi.org/10.1074/jbc.271.4.2023.

11. Adimoolam S, A J. Identification of a domain of lecithin-cholesterol acyltransferase that is involved in interfacial recognition. Biochem Biophys Res Commun. 
1997;232(3):783-787. Available from: 10.1006/bbrc.1997.6375.

12. Rousset X, Shamburek R, Vaisman B, Amar M, Remaley AT. Lecithin Cholesterol Acyltransferase: An Anti- or Pro-atherogenic Factor? Current Atherosclerosis Reports. 2011;13(3):249-256. Available from: 10.1007/s11883-011-0171-6; https: //dx.doi.org/10.1007/s11883-011-0171-6.

13. Calabresi L, Simonelli S, Gomaraschi M, Franceschini G. Genetic lecithin:cholesterol acyltransferase deficiency and cardiovascular disease. Atherosclerosis. 2012;222(2):299-306. Available from: 10.1016/j.atherosclerosis.2011.11.034; https: //dx.doi.org/10.1016/j.atherosclerosis.2011.11.034.

14. Levison SS, Wagner SG. Implications of reverse cholesterol transport: recent studies. Clin Chim Acta. 2015;439:154-161. Available from: 10.1016/j.cca.2014.10.018.

15. Ossoli A, Simonelli S, Vitali C, Franceschini G, Calabresi L. Role of LCAT in Atherosclerosis. Journal of Atherosclerosis and Thrombosis. 2016;23(2):119-127. Available from: 10.5551/jat.32854; https://dx.doi.org/10.5551/jat.32854.

16. paraoxonase 1 Activity Assay Kit (ab241044) Abcam, Japan. Version 1 Last updated 29th; 2018. Available from: https://www.abcam.com/paraoxonase-1-activity-assaykit-ab241044.html.

17. LCAT Activity Assay Kit 1. (ab242306) - Abcam, Japan. Version 1 Last updated 13th; 2018. Available from: https://www.abcam.com/ps/products/242/ab242306/ documents/ab2.

18. IBM SPSS Statistics for Windows, Version 26.0. Armonk, NY: IBM Corp; 2019.

19. El-Melegy NT, Mohamed NA, Sayed MM. Oxidative Modification of LowDensity Lipoprotein in Relation to Dyslipidemia and Oxidant Status in Children With Steroid Sensitive Nephrotic Syndrome. Pediatric Research. 2008;63(4):404409. Available from: 10.1203/pdr.0b013e3181647af5;https://dx.doi.org/10.1203/ pdr.0b013e3181647af5.

20. zewska MHK, Obuchowicz AK, Wielkoszyński T, Zmudzińska Kitczak J, Urban K, Hyla-Klekot L. Evaluation of certain constituents of antioxidant defense in youth treated in the past for steroid-sensitive idiopathic nephrotic syndrome. Pediatric Nephrology. 2009;24(11):2187-2192. Available from: 10.1007/s00467-009-1269-8; https://dx.doi.org/10.1007/s00467-009-1269-8.

21. $\mathrm{Hu}$ P, Lu L, Hu B, Du PF. Characteristics of lipid metabolism under different urinary protein excretion in children with primary nephrotic syndrome. Scandinavian Journal of Clinical and Laboratory Investigation. 2009;69(6):680-686. Available from: 10.3109/00365510902980751;https://dx.doi.org/10.3109/00365510902980751.

22. Vijayetha P, Patil1 AB, Patil2, Vidya S, Patil3, Deepti G. Ingleshwar: Paraoxonase Activity and Lipid Profile in Paediatric Nephrotic Syndrome: A Cross-sectional. Study Journal of Clinical and Diagnostic Research. 2016;10(3):17-20.

23. Nishi S, Ubara Y, Utsunomiya Y, Okada K, Obata Y, Kai H, et al. Evidence-based clinical practice guidelines for nephrotic syndrome 2014. Clinical and Experimental Nephrology. 2016;20:342-370. Available from: 10.1007/s10157-015-1216-x; https: //dx.doi.org/10.1007/s10157-015-1216-x. 
24. Al-Assadi AB, Mohammed NA, Ali SH. SERUM IMMUNOGLOBULING, M AND A LEVELS IN CHILDREN WITH NEPHROTIC SYNDROME AND ITS CORRELATION WITH BIOCHEMICAL PARAMETERS. Pakistan Journal of Biotechnology. 2018;15(4):1011-1016.

25. Dobiasova M. Atherogenic Impact of Lecithin-Cholesterol Acyltransferase and Its Relation to Cholesterol Esterification Rate in HDL (FERHDL) and AIP [log(TG/HDL-C)] Biomarkers: The Butterfly Effect? . PHYSIOLOGICAL RESEARCH. 2017;66(2):193-203. Available from: 10.33549/physiolres.933621.

26. Eroglu E, Kocyigit I, Unal A, Korkar H, Karakukcu C, Orscelik O, et al. Serum paraoxonase activity is associated with epicardial fat tissue in renal transplant recipients. International Urology and Nephrology. 2015;47(8):1409-1414. Available from: 10.1007/s11255-015-1051-8; https://dx.doi.org/10.1007/s11255-015-1051-8.

27. Yokoyama S, Fukushima D, Kupferberg JP, Kézdy FJ, Kaiser ET. The mechanism of activation of lecithin:cholesterol acyltransferase by apolipoprotein A-I and an amphiphilic peptide. Journal of Biological Chemistry. 1980;255(15):7333-7339. Available from: 10.1016/s0021-9258(20)79708-5;https://dx.doi.org/10.1016/s00219258(20)79708-5.

28. Parks JS, Huggins KW, Gebre AK, Burleson ER. Phosphatidylcholine fluidity and structure affect lecithin:cholesterol acyltransferase activity. Journal of Lipid Research. 2000;41(4):546-553. Available from: 10.1016/s0022-2275(20)32402-0; https://dx.doi.org/10.1016/s0022-2275(20)32402-0.

29. Ece A, Atamer Y, Gürkan F, Davutoğlu M, Koçyiğit Y, Tutanç M. Paraoxonase, total antioxidant response, and peroxide levels in children with steroid-sensitive nephrotic syndrome. Pediatric Nephrology. 2005;20(9):1279-1284. Available from: 10.1007/ s00467-005-1956-z;https://dx.doi.org/10.1007/s00467-005-1956-z.

30. Rozek LS, Hatsukami TS, Richter RJ, Ranchalis J, Nakayama K, McKinstry LA, et al.. The correlation of paraoxonase (PON1) activity with lipid and lipoprotein levels differs with vascular disease status. Elsevier BV; 2005 . Available from: 10.1194/jlr.m400489-jlr200;https://dx.doi.org/10.1194/jlr.m400489-jlr200. 